\title{
A Living Wage for The Bahamas: Estimates, Potentials, and Problems
}

\author{
Lesvie Archer \\ (iD) 0000-0003-3278-7824 \\ Bridget Sophia Hogg \\ (iD) 0000-0002-4745-9367 \\ Vijaya Perumal \\ 0000-0002-3663-8597 \\ Olivia Saunders \\ 0000-0003-2613-3074 \\ Brittney Johnson \\ iD 0000-0002-1587-7353

\section{University of The Bahamas}

\section{Abstract}

This report describes how living wage estimates were calculated for New Providence and Grand Bahama. This report uses primary and secondary sources and is inspired by the Anker methodology. We calculated that \$2625 and \$3550 were needed each month as the gross living wage for a full-time worker who must sustain a family of four in New Providence and Grand Bahama, respectively. We estimated the net living wage to be $\$ 2500$ per month for New Providence and $\$ 3400$ for Grand Bahama. Our estimates are almost 200\% higher than the minimum wage and nearly $130 \%$ higher than the poverty line for New Providence; for Grand Bahama, they are almost 300\% higher than the minimum wage and 160\% higher than the poverty line. The study should inform national discussions on public policy matters related to reducing the country's cost of living, improving its income equity, and pursuing economic justice for all.

\section{Introduction}

Low wage workers across The Bahamas regularly lament that their salaries cannot adequately support a decent lifestyle for them and their families. Even prior to the onset of the COVID-19 pandemic, and the accompanying substantial job losses, a May 2018 study by the Central Bank of The Bahamas supported workers' claim, revealing that nearly $50 \%$ of workers in The
Bahamas struggle to satisfy daily living costs and "cannot make ends meet" (Hartnell, 2018, para. 9). Hence, while The Bahamas is often labelled by global governing agencies as a high-income county (World Bank, 2019), this ranking can mask income inequality (Lowe, 2012; Inter-American Development Bank, 2018) and is nonreflective of the income and lifestyle of the so-called average Bahamian. While low income is usually tied to poverty through a 
lack of education (Krueger \& Malečková, 2005; Moss-Knight \& Carroll, 2013), recent research on the cycle of poverty in The Bahamas shows that even persons who complete higher education may be unable to earn enough to meet their annual household expenditures (Russell, 2019; Bahamas Department of Statistics, 2016). The additional threat of increasing government taxes and high living costs prompted at least one Bahamian trade union leader to claim that "more than $70 \%$ of civil service salaries [already] go to loan deductions" (Wells, 2018, para. 11). Whether these loan deductions and the corresponding inability to cover living costs are due to the actual burden of poverty or to the desire to elevate one's present circumstance and lifestyle remains a hotly contested issue (e.g., see Stevenson, 2016). Overall, for low wage workers, maintaining a basic but decent standard of living in The Bahamas appears to be a challenging, multifaceted endeavour.

\section{Defining a Living Wage}

A living wage refers to the income required to sustain a worker's physical, emotional, social and cultural needs, as well as the needs of that worker's family beyond mere subsistence (Anker \& Anker, 2017). A living wage may be construed as a basic human right (United Nations, 1948). However, it is recommended that the implementation of living wages be guided by the coconsideration of economic factors such as levels of development, productivity, and employment (International Labour Organization, 1970, Article 3). Chief tenets that undergird implementation of living wages include poverty eradication and the assurance that if persons work, they have a right to a decent standard of living. The term decent is subject to debate but can be clarified as an economic concept pending simple adherence to clear and transparent rules and standards (Anker \& Anker, 2017). For example, while working families generally use overtime pay to support their livelihoods and to rise out of the working class (Shierholtz, 2019; Fielding et al., 2019), a living wage offers decency by ensuring that workers need not work overtime, nor a second or third job to make ends meet (Anker \& Anker, 2017). Certainly, questions surrounding a 'decent' standard of living, and the cost of maintaining such a standard in The Bahamas beckon greater consideration; however, this living wage project offers a step in the right direction.

\section{Benefits and Disadvantages of a Living Wage}

Benefits of implementing a living wage extend to workers, employers, the economy, the government and society at large. Workers can receive fair compensation, a better quality of life, improved health and work reduced hours (Marshall \& Weil-Accardo, 2019). Employer benefits include "decreased employee turnover, cost savings for staff hiring and training, improved job quality, productivity and service delivery, lower absenteeism" and recognition for being a responsible employer (Wayland, 2011, p. 1). Societal benefits include greater consumer spending and local shopping, reduced dependency on government resources and social agencies, and greater restrictions on the import of foreign labour (Anker \& Anker, 2017; Horton \& Wills, 2018; Wayland, 2011), which may lead to employers making greater investments in local training, productivity, and innovation (Sergievskaya 2021). Lastly, in addition to reducing poverty and its affiliated costs, standardizing a living wage may help reduce a country's gender pay gap (Anker \& Anker, 2017); such a benefit may even effect a change in the socialized attitudes of young Bahamians who tend to demonstrate a negative bias concerning the socio-economic role and value of females (Fielding \& Ballance, 2019). 
Arguments against the introduction of a living wage include employer concerns about job losses and their inability to meet the wage rate due to overhead costs and cash flow restraints (Hartnell, 2021; Bartik, 2004). Also, while a living wage is a predominantly voluntary initiative, some consider it inappropriate to hold employers alone responsible for providing their workers with a living wage (McMaken, 2015) because a society's cost of living is determined by factors that extend beyond an employer's control. Government-supported alternatives also exist, including universal basic income and earned tax credits. Overall, implementing a living wage facilitates the socio-economic empowerment of workers, an important development strategy.

\section{Methodology}

\section{Estimating a Living Wage for the Archipelago}

Although an archipelagic nation of thousands of islands, cays and islets, The Bahamas' population of nearly 400,000 reside mainly on less than 20 of the islands. Approximately $80 \%$ of the residents live in New Providence (Inter-American Development Bank, 2018). This urbanized island is home to Nassau, the country's capital, and is frequently the focus of empirical studies conducted on the country's social and economic culture. However, because each island operates at a different level of development and dependency (Inter-American Development Bank, 2018), what may be considered the minimum cost of decent living in New Providence may not apply for Grand Bahama, the nation's second most populous island, and may vary between islands. As a nation that imports most of its consumer goods, Nassau, the capital city on New Providence Island, serves as a hub for associated warehousing, administrative, and distribution activity. New Providence takes large import orders, breaks them down, and distributes them to the remaining islands, also known as Family Islands, some of which are hundreds of miles apart (for example, the distance between the islands of Great Inagua and New Providence is 375 miles). Accordingly, the cost of living on each island is significantly determined by the cost of shipping products and services. For example, the price of gasoline in Inagua was $\$ 6.40$ per gallon (Kelly, personal communication, March 11, 2020), compared to $\$ 4.46$ in Nassau as noted in the Gas Tracker section of The Nassau Guardian newspaper. This difference in just one living expense between two islands in the Bahamas demonstrates the importance of sensitivity and respect for each island's particular socioeconomic context. Each island represents a distinct market with distinct utility, food, and housing expenses, owing to infrastructure and development constraints (Karagiannis et al., 2012). As a result, the living wage estimate developed in this study should not be applied nationally and is better seen as part of a wider effort aimed at developing a national living wage range. This project, therefore, was intended to constitute a larger work that seeks to calculate a living wage range for the entire country based upon estimates produced for each part of the Bahamian archipelago. At the same time, while this effort to customize the living wage estimate for each island or zone aligns with the practice of some archipelagic nations to customise their minimum and living wage rates across each island or zone (e.g., Association of Southeast Asian Nations), The Bahamas' national minimum wage rate is standardized across all islands (Osadebay, 2005), equally to $\$ 5.25$ per hour, $\$ 42$ per day (an 8-hour shift), or $\$ 210$ per week (a 5-day workweek; Gibson, 2015). 


\section{Anker and Anker Methodology}

A plethora of methods exist for estimating a living wage. For example, the minimum income standard method is used in the United Kingdom, while researchers at the Massachusetts Institute of Technology developed a formula to calculate the living wage for metropolitan cities in the United States (Glasmeier, 2004). The so-called Anker method (Anker \& Anker, 2017) used in this study is well established in many countries throughout the developing world, not limited to Belize, Costa Rica, Brazil, Mexico, Kenya etc. (cf. Voorend et al., 2021). Our living wage estimate follows the Anker methodology not only because of its common usage in developing countries, but also because of its comprehensiveness, costeffectiveness, and efficiency. Anker and
Anker (2017) recommend assessing within the chosen fieldwork area, the cost of food, housing and utilities, other essential needs, as well as the need to safeguard against emergencies and unexpected events. Researchers are then asked to add the normal family size and the ratio indicating the likelihood that adults in the reference family worked full-time to cover these costs. A visual presentation of the Anker method is shown in Figure 1.

The paper is based on the published report that details the primary and secondary data sources used to calculate these expenses and factors, (notably Archer et. al, 2021). All calculations are reported as rounded estimates, and their details are published in Archer et al. (2021).

\section{Figure 1}

Anker Methodology for Estimating Living Wage.

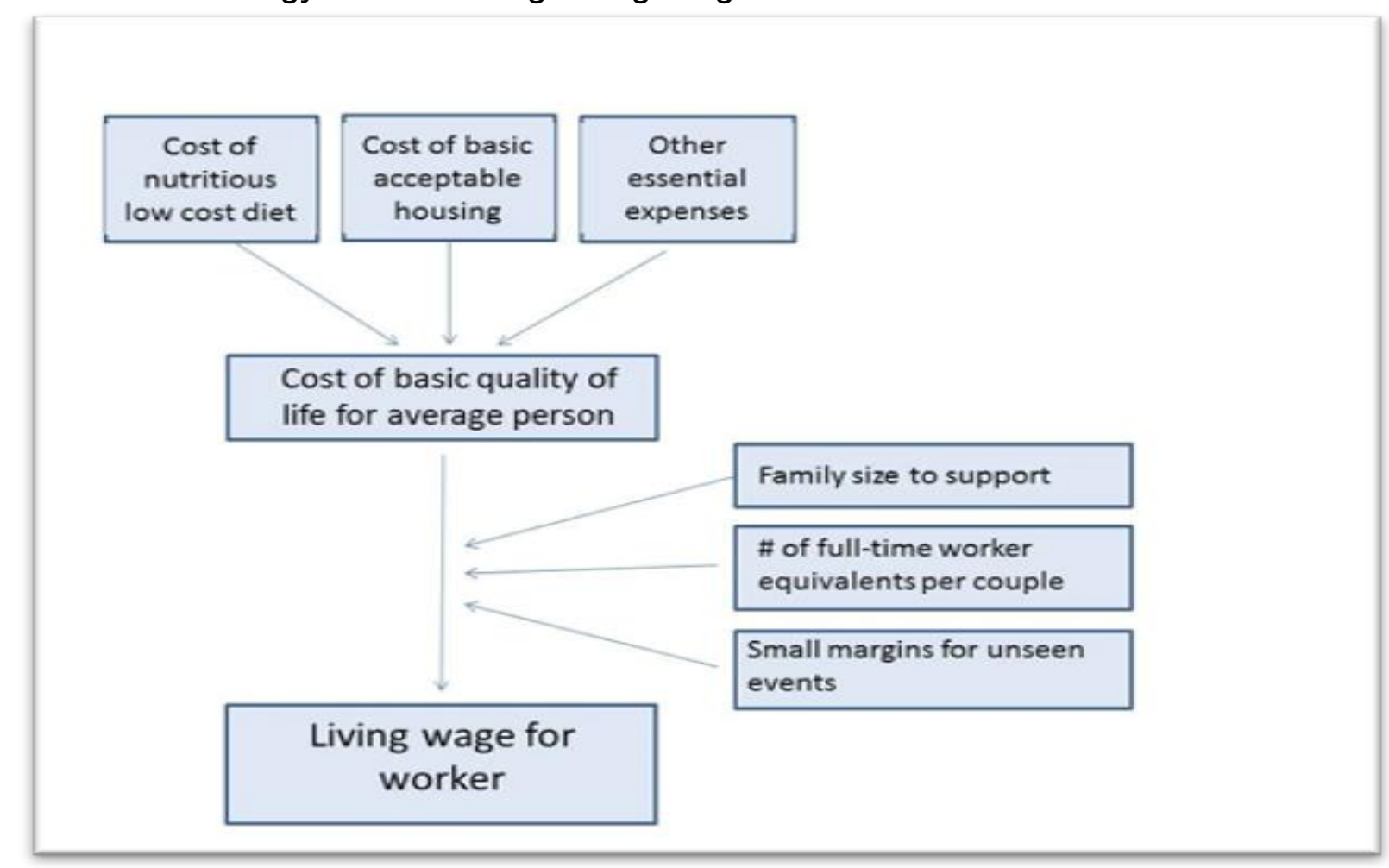

Note: From: Living Wages Around the World: Manual for Measurement, R. Anker \& M. Anker, p, 19. Copyright 2017 by Edward Elgar. Reprinted with permission. 
Figure 2.

Map of New Providence with fieldwork areas circled.

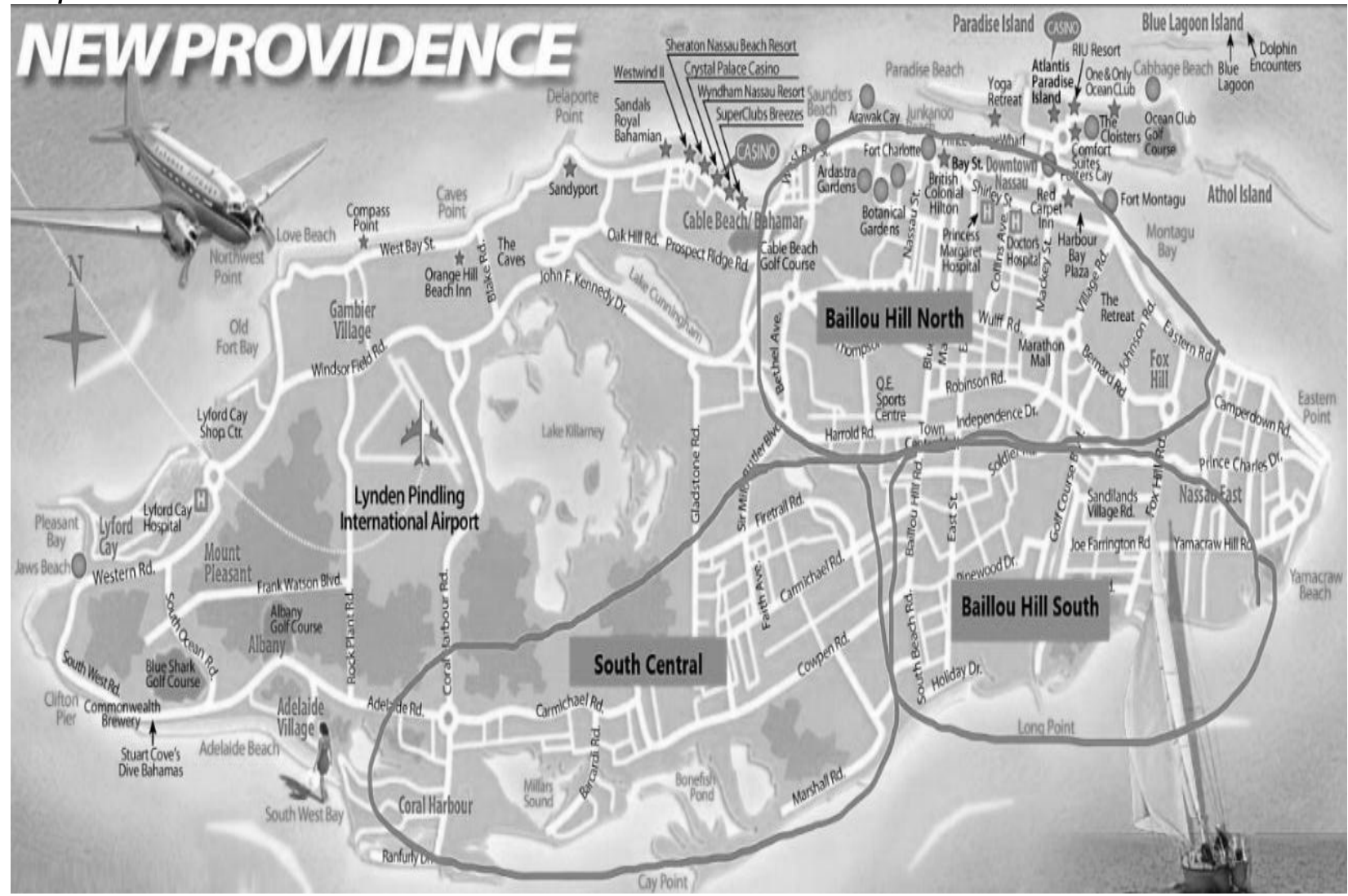

Note: From: The Bahamas Living Wages Survey, Archer et al, p. 9. 2021.

\section{Fieldwork Areas}

To conduct our research, we divided New Providence Island into four regions: Central, Baillou Hill South, Baillou Hill North, and South-Central. Three of these regions, Baillou Hill South, Baillou Hill North, (separated by Baillou Hill Road), and SouthCentral, were the focus of this study. We excluded Central New Providence from our study because it is largely middle class and tourist oriented. Figure 2 presents a map of New Providence with fieldwork areas circledGrand Bahama previously hosted approximately $15 \%$ of the population but in September 2019, a number of Grand Bahamians relocated to New Providence following the island's devastation by Category 5 Hurricane Dorian, which destroyed a significant proportion of the built environment on the island's east end (Kijewski-Correa et al., 2021). Consequently, our investigation concentrated on three settlements in the western part of the island: Freeport proper, Eight Mile Rock, and West End. Since Grand Bahama had been selected as the second site of study before the hurricane, we chose to proceed with the study on this island. While recognising that the costs may not accurately reflect the long-term cost of living in Grand Bahama following the Dorian disaster, we must also consider that the cost of living calculated by our estimate may represent reality for an extended period as the island attempts to rebuild its community. Figure 3 presents a map of Grand Bahama with fieldwork areas circled. 


\section{Figure 3.}

Map of Grand Bahama with fieldwork areas circled.

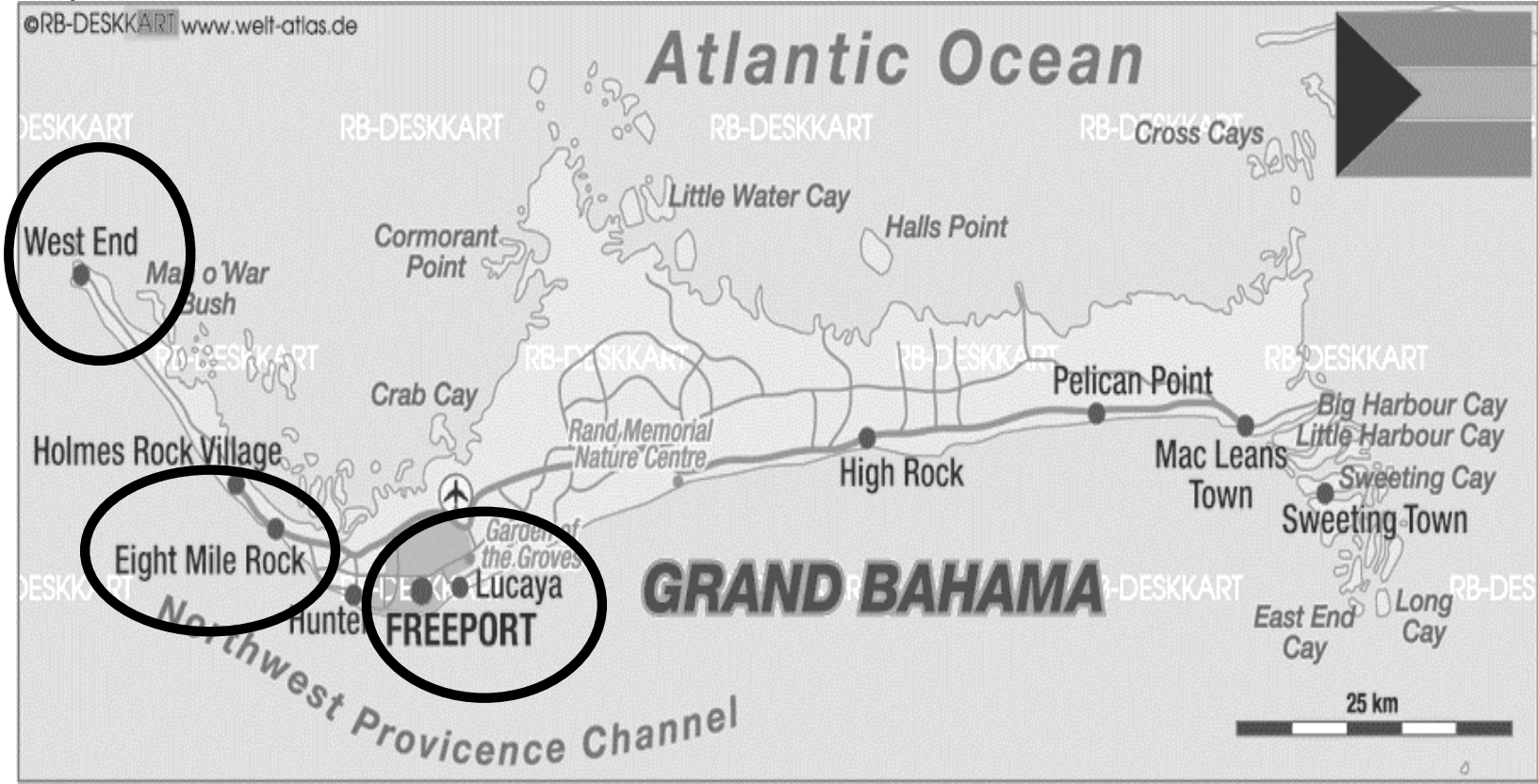

Note: From: The Bahamas Living Wages Survey, Archer et al, p. 10. 2021.

\section{Model Diet and Food Costs}

Local nutritionists constructed our model diet, adhering to Anker and Anker's (2017) living wage model diet principles of nutritious, locally palatable, and affordable. To the best of our knowledge, no locally constructed diet yet existed for the specific purpose of estimating the cost of food for a liveable income. Further, while the breadbasket items used to construct the poverty line for the Bahamas Department of Statistics Household Expenditure Survey 2013 Report (2016) considered nutritional content, low cost, and included variety, when vetting the list against what minimum wage workers reported to us as their typical grocery purchases, discrepancies arose. For example, the poverty line breadbasket options contain liver, pig's feet, and canned beef [sic], yet our interviewees identified chicken quarters, turkey, pork chops and fish as their most frequent purchases; this discrepancy may be related to our team's decision to focus on the third quintile of those interviewed for the Household Expenditure Survey 2013 Report, in contrast to the tendency of poverty line breadbaskets to focus on the minimum breadbasket requirement (AndersonJohnson, 2014). Overall, our living wage model diet adheres to World Health Organization micro- and macro- nutrient standards: $1-15 \%$ protein, $15-30 \%$ fat, 55$75 \%$ carbohydrates (Anker \& Anker, 2017). Per our nutritionists' advice, our diet also considers calorie intake using estimates of a western standard body mass index of 24 (Centers for Disease Control and Prevention, 2021) and an average calorie intake of 2,128 per person per day. Following Anker and Anker (2017), our diet cost also accounted for variety, cultural seasonings etc., and spoilage habits. 


\section{Local Food Prices}

We collected prices for each food item from 14 grocery stores, convenience stores, and wholesalers (11 in New Providence and 3 in Grand Bahama). We recorded more than 700 prices from low-cost and pre-packaged items. We used the Anker Excel model diet programme and the Anker Excel calorie requirement programme (Anker \& Anker, 2017, Suppl.) to ensure that the food quantities and nutritional components aligned with international standards.

Given that measurements in The Bahamas are typically recorded using the imperial system, our team converted collected data on food weights to metric units prior to inserting it into the Anker Excel programmes that operate using the metric system.

Importantly, both our local nutritionists and the Anker Excel program separated our list of food items into edible grams and purchased grams to distinguish between the weight of a purchased food item and the weight of a food's edible parts. For example, an average banana purchased from the store may weigh around 187 grams which translates into an estimated 150 calories; however, because the skin of the banana is usually not eaten, the edible weight is around 115 grams (https://fdc.nal.usda.gov/fdc-app.html\#/food -details/1105314/measures), resulting in a calorie intake of around 100 (https://fdc.nal.usda.gov/fdc-app.html\#/food -details/1105314/nutrients). Distinguishing between purchased and edible weight helps nutritionists and researchers better determine the actual quantity of calories being consumed, which leads to better cost estimations of a particular diet (Anker \& Anker, 2017).

\section{School Free-Lunch Programme}

To ensure this model diet is the lowest possible cost, Anker and Anker (2017) argue that the model diet for a living wage reference family should include the cost of food given through the country's national free school lunch program. In The Bahamas, this programme employs venders to offer free, healthy lunch to students enrolled in primary and secondary public schools, provided their parents earn minimum wage or less and are Bahamas citizens or permanent residents. To calculate the value of the school free lunch programme to our reference family, we considered the length of school year, number of children in our reference family, and the ages/grades with access to the free lunch programme.

\section{Housing, Utility, and other Housing- related Costs}

Anker and Anker (2017) argue that using secondary sources to obtain information on the housing conditions of residents may lead living wage researchers to record housing and utility expenses that do not represent a decent lifestyle. For example, the Household Expenditure Survey 2013 Report (Bahamas Department of Statistics, 2016) explains that persons in decile three spend around $\$ 2,577$ on housing, water, electricity, gas, and other fuels (p. 24); however, this consumption expenditure average does not indicate the quality of housing or electricity needs. Living wage research studies conducted by Anker and Anker (2017) confirm that a low electricity bill may indicate that a family uses only one lightbulb at home and constantly move it around to save costs, which is not in alignment with the earlier-mentioned definition of a decent standard of living. Therefore, to avoid replicating poverty patterns that may be present in data derived from secondary sources, we alternatively visited neighbourhoods where minimum wage workers lived, and in line with Anker and Anker (2017), examined whether their rented accommodation aligned with both 
minimum international and local housing standards. To guide this fieldwork expedition, we referred to the international minimum housing standards and the government of The Bahamas national housing standard (Bahamas Ministry of Works and Utilities, 2003). We collected data on 30 rented dwellings on New Providence. In Grand Bahama, we focused on the homes still intact after Hurricane Dorian; these included rental properties and as well as owner-occupied residences in Freeport, Eight Mile Rock, and West End. We asked the participants to estimate the average cost of their monthly water, electricity, and Internet bills.

Our migrant interviewees repeatedly voiced their worry about their dwelling sites being discovered, photographs being taken, and generating conflict with their landlords, despite their comprehension of the study's permission form's promise of anonymity. As a result of this hesitation, we adjusted our technique to make the survey easier to complete for them, as well as for our Haitian and Latino minimum-wage interviewees. Resultingly, we triangulated the housing data for New Providence using primary and secondary sources. Five house visits and inspections, nine completed surveys, and the use of secondary data resulted in the identification of 11 pre-approved rental properties from University of The Bahamas off-campus database. This strategy of using housing accommodations that received preapproval was adopted from the living wage benchmark study completed in Kenya (Anker $\&$ Anker, 2014). The small number of houses surveyed by our research team provides a useful starting point for understanding the living expenses of residents in the capital, and rental and utility expenses were found to be comparable across all three sources.

\section{Non-Food Non-Housing Costs}

Non-food, non-housing (NFNH) costs include apparel and shoes, interior home furnishings and appliances, common home maintenance, miscellaneous items (personal care, banking and financial services, etc.), alcoholic drinks, transportation, communication, leisure and traditions, restaurant dining, and health care and education. NFNH estimates were based on secondary data sources with the goal of avoiding the complexity associated with computing such figures from primary data alone (Anker \& Anker, 2017). We analysed the Household Expenditure Survey 2013 Report (2016), which collected data on the average cost of NFNH needs for families in The Bahamas. Accepting that this survey's first and second decile largely represent consumption practices of the poor and unemployed and are likewise disproportionately populated by Haitian nationals (Bahamas Department of Statistics, 2013), these first two deciles inadequately represent this study's target minimum-wage worker. Therefore, to obtain data from a more balanced sample pool, we selected the third decile of the Bahamas Department of Statistics Household Expenditure Survey 2013 Report (2016).

In accordance with Anker and Anker (2017), we modified the Household Expenditure Survey 2013 Report (2016) NFNH expenditures to account for meals eaten away from home by separating the cost of restaurant and hotel dining into the cost of food and the cost of associated preparation and service taxes; following standard estimates conducted by Anker and Anker in the United States (2017), we split restaurant meal percentage from the survey $(4.4 \%)$ into equal percentages, allocating half to cover the cost of food alone $(2.2 \%)$ and half to cover restaurant service, tax and related costs (2.2\%). The adjusted total of these NFNH 
costs produced a NFNH-food ratio of 1.8 which we multiplied by the reference family's monthly model diet expenditure (that already took into consideration the cost of government school lunches).

\section{Unexpected Events \& Savings}

Researchers estimating a living wage frequently add a percentage to account for unexpected events; in many living wage calculations, this amount ranges between 5\% and 15\%. (Anker \& Anker, 2017). We selected the conservative $5 \%$ estimate. Debt and interest payments are removed from our computation of a living income on the assumption that a living salary will keep individuals out of burdensome debt relationships. Additionally, we added a 5\% buffer for savings and investment to our calculation. This provision was taken into account while calculating the liveable wage for Jamaica (Marsh \& Roberts, 2017. Although this provision is not explicitly stated in the Anker approach, the addition of this category is predicated on the generally accepted understanding that workers strive to improve their circumstances or professional skill sets.

\section{Number of Full-time Workers per Family}

Although our reference family of four includes two adults, thus two potential income-generating workers, Anker and Anker (2017) argue it is unlikely that all workers in a low wage-earning family will be employed or working full-time. To consider the likelihood that the male and female adults in our reference family work full-time, our liveable wage estimate is thus informed by a ratio that uses data obtained from the Bahamas Department of Statistics on the average participation rate for men and women (Leona Wilson, personal communication, February 17, 2020). Our calculations in Archer et al. (2021) found that the likelihood that an adult (aged 20-64) had full-time employment in 2019 stood at $77 \%$ in New Providence and 69\% in Grand Bahama. When we added the assumption that at least one adult in the family is likely employed full-time. We arrived at a ratio of 1.77 and 1.69 for full-time equivalent workers per family, respectively. Accordingly, we divided our living wage salary estimate produced thus far by this ratio to determine the net living wage estimate needed by one full-time worker on each island. We then added the average monthly statuary deductions (national insurance and union dues) to our living wage calculation to produce a gross living wage estimate.

\section{Results}

Keeping in mind that one Bahamas dollar operates as the equivalent to one United States dollar, our estimates reveal that a family of four (two adults and two children) require $\$ 4400$ and $\$ 5750$ per month to maintain a basic but decent standard of living in New Providence and Grand Bahama, respectively. This estimate includes the cost of food, housing, and non-food non-housing costs, plus the amount taken for savings and investments purposes and for unexpected events and sustainability. It also takes into account the government's statutory deductions, namely, the country's $3.9 \%$ obligatory national insurance deduction (National Insurance Board, 2020), and a \$25 union dues rate (based upon the monthly fee charged to members of the Bahamas Public Service Union). Our net and gross wage estimates consider the reality that both adults in the reference family may not be working full-time and represent the wage amount that the full-time worker needs to earn to sustain their family of four. The net wage estimate is $\$ 2500$ for New Providence and \$3400 for Grand Bahama and excludes monthly statutory deductions. With statutory 
deductions included, our gross living wage estimate is \$2625 for New Providence and $\$ 3550$ for Grand Bahama. Although our living wage rates are presented as rounded estimates, they are conservative figures. The model diet is remarkably simple, consisting only of items that are consumed locally, are readily available, and are inexpensive. The housing standards were derived from a combination of the internationally defined standards as well as the local standards, which proved similar.

\section{Figure 4.}

New Providence Living Wage Estimate in Context

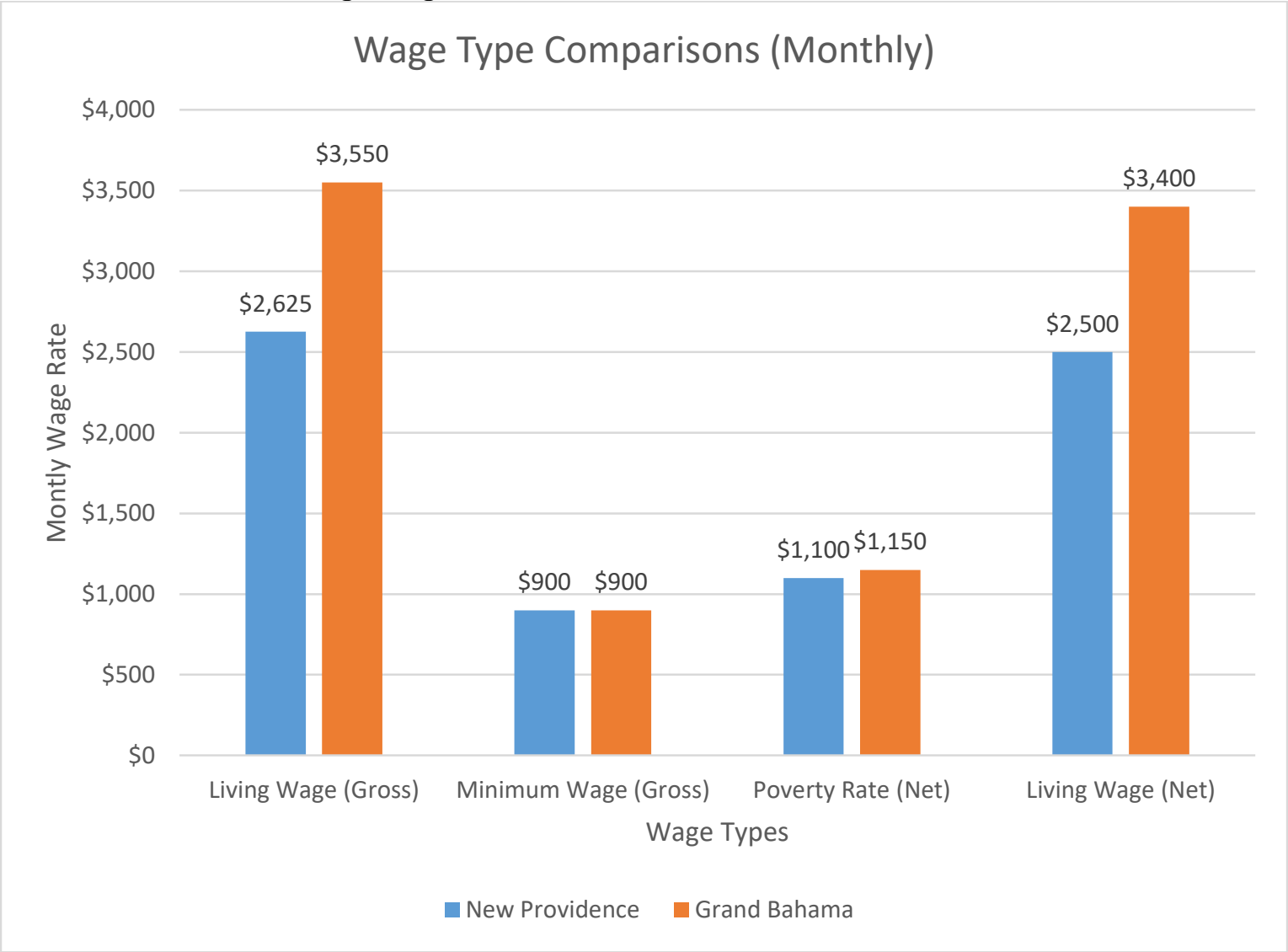

Note: From: The Bahamas Living Wages Survey, Archer et al, p. 10. 2021.

\section{Discussion}

Anker and Anker (2017) argue that contextualising living wage estimates by comparing them with other wage calculations and economic indicators helps to provide an appropriate historical context and also helps demonstrate the gap between current wages and a liveable income. To contextualise our findings, we compared the net living wage estimate to the 2013 poverty line (which does not account for statutory deductions), and the gross estimate to the national minimum wage (from which statutory deductions are withdrawn). The Household Expenditure Survey 2013 Report (2016) identified an Engle coefficient of 0.35 , which we multiplied by the final food basket cost 
(\$4.73 per day) constructed to measure the poverty rate (Anderson-Johnson, 2014). Our calculations produced a 2013 poverty rate of $15.5 \%$, or one out of every six residents. This rate is the latest available nationally and was calculated prior to the introduction of value added tax (VAT) in 2015 and the COVID-19 pandemic. Archer et. al (2021, p. 33) presents a bar chart of our comparison based upon the estimate we produced for each island. Our comparisons reveal that the Grand Bahama living wage estimate is nearly $300 \%$ and $200 \%$ higher than the country's national minimum wage and 2013 poverty line, respectively. Our New Providence living wage estimate is nearly $200 \%$ and $100 \%$ higher than the country's national minimum wage and poverty line, respectively. These indicators not only confirm that the minimum wage rate does not ensure workers live above the poverty line, but also suggest that much needs to be done to ensure that everyone who works can live decently.

Shortly after the government of The Bahamas increased VAT from $7.5 \%$ to $12 \%$ in 2018 , trade union leaders used local media outlets to call for either an increase in the country's national minimum wage or for the establishment of a living wage, with this call echoing in more recent news articles (McKenzie, 2021). Public feedback continues to suggest a division that resembled the well-known contention between absolute and relative poverty (Hartnell, 2021; Foster, 1998). While some members of the public expressed sympathy and agreed that living costs on New Providence are too high, others accused Bahamians who earned low wages as suffering from trying to keep up with the Joneses. This latter argument resonates with McKay's (2004) grievance with those who advocate implementation of a living wage. She questions the existence of real poverty that a living wage seeks to eradicate, when households choose to allocate resources to spend on non-essentials, yet lack socially defined necessities. According to the United Nations' Minimum Wage Convention, however, wages should ensure workers and their family can live decently, as active participants in all facets of society (United Nations, 2002). Minimum wage and living wage advocates both share this foundational premise. As a result, living wage advocates ensuring workers live decently, are able to afford necessities and non-essentials in a way similar to those who are not experiencing poverty (Deeming 2017). To this end, our living wage estimate provides concrete evidence in support of low-wage workers who complain about the struggle to meet living costs; their concerns are valid.

Although our living wage estimate is nearly twice the national poverty line and nearly three times the minimum wage, we used a conservative approach: the model diet included basic foods that are consumed locally, are readily available, and inexpensive; the housing standards were derived from international and local minimum standards; and the NFNH costs were derived from the expenditure practices of the individuals who ranked in the third lowest percentile of the population, right above the poverty line. Unsurprisingly, our comparisons reveal that the current minimum wage is lower than the country's 2013 poverty line. Our findings align with the findings of living wage studies generally, as estimates generated are higher that the poverty rates and minimum wages in the countries studied (e.g., Marsh, O'Connor, \& Roberts, 2017; Anker \& Anker, 2017). With the country introducing VAT at $7.5 \%$ in 2014 and then raising the rate to $12 \%$ in 2018 , the poverty rate is likely higher, even prior to the devastation experienced in 2019 as a result of Hurricane Dorian and the ongoing economic fallout due to the COVID-19 pandemic which started in 2020 . 
Concerning our model diet and food budget findings, there are numerous and significant discrepancies between previously created food baskets and our living wage model diet. For instance, the poverty line diet indicated a high reliance on processed meats such as hotdogs and salami sausage, which are nutritionally deficient. We substituted these items with low-cost fresh and frozen meats that are also widely consumed, such as chicken. Herein, we also decreased the number of food items by focusing on healthier alternatives. Also, fresh fish is not included on the VAT-free list or in the Ministry of Health's food basket. However, when we questioned low-wage employees to verify the appeal of the model diet constructed by our nutritionists, we discovered that fresh fish was their second favourite meat purchase, trailing only chicken. As a result, we incorporated fresh fish into our model diet. Another significant distinction was the variety of fruits and vegetables included in each diet. While our living wage model diet includes fruits and vegetables that represent a healthful and balanced diet, neither the poverty line consumption breadbasket (also called food basket) nor the government's VAT-free breadbasket does. In comparison to the food basket calculated by the Ministry of Health, our model diet has fewer calories (2180 calories as opposed to 2400 calories). In contrast to the Ministry of Health's VAT-free breadbasket (2018), which has no fruit, vegetable or legume options, our model diet includes a variety of fruits, vegetables, and legume options. Finally, our model diet cost also includes additional monies for variety, which enables workers to purchase items that may not necessarily be reflected in our model diet.

We believe our decision to use the Anker and Anker approach enables components of our living wage estimate to also prove a useful guide to agencies, organisations, and institutions in several ways. For example, the model diet and food budget can be used to identify gaps in social assistance support, which can direct support efforts offered by charitable, non-governmental and non-profit agencies.

For The Bahamas specifically, we expect that our findings will inform both public and private sector policy on wage payment to workers, particularly those at the bottom end of the wage range. Finally, the implications of this study can serve as a catalyst for discussion on issues of quality of life, economic justice, as well as give input into policy considerations on these subjects. The findings can also affect poverty reduction strategies that can be strategically marketed as alternatives to the implementation of a living wage. For example, in that this study confirms that the cost of living is high, it may encourage private and government efforts to implement strategies that reduce cost of living expenses.

\section{Limitations}

A key limitation of this study concerns the lack of industry specification and consideration of in-kind benefits. Future research projects may include customizing this wage to specific industries. For example, if in the hotel industry, all low-wage hotel workers are provided with free meals, transportation to/from work, and receive gratuity payments; such provisions count as an in-kind benefit, and per Anker (2017), the cash value of our general living wage estimate may be reduced accordingly. Another limitation concerns recognition that only a small number of houses were surveyed, which means the results do not necessarily reflect the wider population. It is nonetheless hoped that this small sample size provides a useful starting point in understanding living expenses for residents of New Providence and of Grand Bahama. 


\section{Conclusion}

Given the increasingly popular belief that "decent work is not possible without decent wages" (Anker \& Anker, 2017, p. 1), the call for low-wage workers to receive a living income or wage is becoming a global demand. Our living wage estimates for New Providence and Grand Bahama show that local worker concerns over cost-of-living expenses are valid and provide opportunities to inform policies related to minimum wage, cost of living expenses and social welfare programmes. Further research may also demonstrate its use value for measuring the effectiveness of government and social support.

\section{References}

Anderson-Johnson, P. (2014). Report of the construction of food basket for poverty calculation for The Bahamas. Department of Statistics.

Anker, R., \& Anker, M. (2014). Living wage for Kenya with focus on Fresh Flower Farm area near Lake Naivasha. Global Living Wage. https://www.globallivingwage.org/living -wage-benchmarks/non-metropolitanurban-kenya/

Anker, R., \& Anker, M. (2017). Living wages around the world: Manual for measurement. Edward Elgar. https://doi.org/10.4337/9781786431462. 00013
Archer, L., Saunders, O., Hogg, B., Perumal, V., \& Johnson, B. (2021). The Bahamas living wages survey: Estimating a living wage for The Bahamas (New Providence and Grand Bahama). University of The Bahamas. https://www.ub.edu.bs/wpcontent/uploads/2016/10/GPPI_LivingWage-Survey_revised_27-May-2021.pdf

Bahamas Department of Statistics. (2016). Household expenditure survey 2013 report. https://www.dloc.com/ AA00064349/00001

Bahamas Ministry of Works and Utilities. (2003). Bahamas building code. (3rd ed.) https://www.bahamas.gov.bs/wps/ wcm/connect/d7ebcbad-f9b6-42e3-aff279f83bd91810/Bahamas\%2BBuilding\% 2BCode\%2B3rd\%2BEd.pdf?MOD=AJP ERES 
Bartik, T. J. (2004). Thinking about local living wage requirements. Urban Affairs Review, 40(2), 269-299. https://doi.org/10.1177/10780874042695 $\underline{39}$

Centers for Disease Control and Prevention. (2021). About adult BMI.

https://www.cdc.gov/healthyweight/asse ssing/bmi/adult_bmi/index.html

Central Bank of the Bahamas. (2018). An analysis of the Bahamas Financial Literacy survey 2018. https://cdn.centralbankbahamas.com/doc uments/2019-06-19-07-42-48-Analysisof-the-Bahamas-Financial-LiteracySurvey-2018.pdf

Deeming, C. (2017). Defining minimum income (and living) standards in Europe: Methodological issues and policy debates. Social Policy \& Society, 16(1), 33-48. https://doi.org/ 10.1017/S147474641500041X

Fielding, W. J., \& Ballance, V. C. (2019). Learning gender-based attitudes in The Bahamas. International Journal of Bahamian Studies, 25(1), 1-15. http://doi.org/10.15362/ijbs.v25i0.339

Fielding, W., Ballance, V., Smith, P., Veyrat-Pontet, A., \& Sutton, H. (Eds.). (2019). Our prisoners: A collection of papers arising from a 2016 survey of inmates at The Bahamas department of correctional services facility at Fox Hill. Inter-American Development Bank. https://doi.org/10.18235/001593

Foster, J. E. (1998). Absolute versus relative poverty. The American Economic Review, 88(2), 335-341. https://www.jstor.org/stable/116944

Gibson, S. (2015). The Bahamas increases national minimum wage. http://www.thebahamasweekly.com/publ ish/bis-news-
updates/House_Communication_by_Bah amas_Labour_Minister_Hon_D_Shane_ Gibson_Increase_in_National_Minimum _Wage43104.shtml

Glasmeier, A. (2004). About the living wage calculator.

https://livingwage.mit.edu/pages/about

Hartnell, N. (2018, May 18). Near 50\% of Bahamians 'cannot make ends meet'. The Tribune. http://www.tribune242.com/ news/2018/may/18/near-50-ofbahamians-cannot-make-ends-meet/

Hartnell, N. (2021, May 14). 'No way on God's earth' is livable wage $\$ 2,625$. The Tribune. http://www.tribune242.com/ news/2021/may/14/no-way-gods-earthlivable-wage-2625/

Horton, A., \& Wills, J. (2018). Impacts of the living wage on in-work poverty. In L. Lohmann \& I. Marx, (Eds.), Handbook on in-work poverty (pp. 228244). Edward Elgar. https://doi.org/10.4337/9781784715632

Inter-American Development Bank. (2018). Country program evaluation: Bahamas 2010-2017.

https://publications.iadb.org/publications /english/document/Country-ProgramEvaluation-Bahamas-2010-2017.pdf

International Labour Organization. (1970). C131- Minimum wage fixing convention, 170 (No. 131). https://www.ilo.org/dyn/normlex/en/f?p $=$ NORMLEXPUB: $12100: 0::$ NO::P1210 0_INSTRUMENT_ID:312276

Karagiannis, N., Katsivela, M., MadjdSadjadi, Z., \& Stewart, D. (2012). Expanding the production possibilities of The Bahamas. International Journal of Business and Social Science, 3(12), 821. http://www.ijbssnet.com/journals /Vol_3_No_12_Special_Issue_June_201 2/2.pdf 
Kijewski-Correa, T., Roueche, D., Kennedy, A., Allen, D., Marshall, J., Kaihatu, J., Wood, R., Smith, D., Lester, H., Lochhead, M., Copp, A., McCarthy, A., Prevatt, D., \& Robertson, I. (2021). Impacts of Hurricane Dorian on the Bahamas: Field observations of hazard intensity and performance of the built environment. Coastal Engineering Journal, 1-21. https://doi.org/10.1080/21664250.2021.1 958613

Krueger, A. B., \& Malečková, J. (2003). Education, poverty and terrorism: Is there a causal connection?. Journal of Economic Perspectives, 17(4), 119-144. https://doi.org/10.1257/08953300377203 4925

Lowe, A. (2012, September 3). Bahamas becoming increasingly unequal. The Tribune.

http://www.tribune242.com/news/2012/s ep/03/bahamas-becoming-increasinglyunequal/

Marsh, L., O'Connor, C., \& Roberts, D. (2017). A living wage for Jamaica: Considerations for calculation and implementation. Social and Economic Studies, 66(1/2), 239-259. https://www.jstor.org/stable/44732910

Marshall, S., \& Weil-Accardo D. (2019) The future of the ILO: A renewed purpose in promoting a global living wage. In K. R Shyam Sundar, (Ed.), Perspectives on neoliberalism, labour and globalization in India (pp. 978-81). Palgrave Macmillan. https://doi.org/10.1007/978981-13-6972-8_8

McKay, S. (2004). Poverty or preference: What do "consensual deprivation indicators" really measure?'. Fiscal Studies, 25(2), 201-223. https://doi.org/10.1111/j.14755890.2004.tb00102.x
McKenzie, N. (2021, May 17). I told you so: "No Surprise" on wage study findings, says union leader. Eyewitness News. https://ewnews.com/i-told-you-so-nosurprise-on-ub-university-of-thebahamas-livable-minimum-wage-studyfindings-says-union-leader-obieferguson-tuc-trade-union-congresspresident

McMaken, R. (2015, September 4). The failed moral argument for a "living wage". Mises Wire. https://mises.org/library/failed-moralargument-living-wage

Moss-Knight, T., \& Carroll, C. (2013). Tailoring a parenting curriculum for the needs of pregnant adolescents in The Bahamas. Journal of Human Behavior in the Social Environment, 23(2), 137-143. https://doi.org/10.1080/10911359.2013.7 47412

Osadebay, E. (2005). Labour law in The Bahamas: An outline. Nassau Guardian.

Russell, P. P. (2019). Why we gatta be da poorest?: Disrupting the cycle of poverty for single mothers in the Bahamas by the assessment of their needs and the mapping of community and educational institutions' resources [Unpublished master's thesis]. Merrimack College. https://scholarworks.merrimack.edu/cgi/ viewcontent.cgi article $=1020 \&$ context $=$ soe_student_ce

Sergievskaya, N. (2021). Migration of people: Pros and cons. IOP Conference Series: Earth and Environmental Science, 678, 012016. https://iopscience.iop.org/article/10.1088 /1755-1315/678/1/012016 
Shierholz, H. (2019, September 24).

Trump's new overtime rule leaves millions of working people behind. Economic Policy Institute. https://www.epi.org/press/the-trumpadministrations-overtime-rule-leavesmillions-of-workers-behind/

Stevenson, M. (2016). "I too grew up poor": Economic discourse and criminality. In. W. Fielding, V. C. Ballance, \& I. G. Strachan, Violence in The Bahamas (pp. 221-238). Media Enterprises. https://ufdc.ufl.edu/AA00078778/00002

United Nations. (1948). Universal declaration of human rights, article 25. https://www.un.org/en/universaldeclaration-human-rights/
Voorend, K., Anker, R., \& Anker, M. (2021). Living wage benchmark report for rural Belize. The Global Living Wage Coalition. https://www.globallivingwage.org/living -wage-benchmarks/living-wage-forrural-belize/

Wayland, S. (2011). The impact on business of adopting living wage policies. Living Wage Hamilton. http://livingwagehamilton.ca/wp/wpcontent/uploads/2011/12/Living-WageBrief_28Nov2011-2.pdf

Wells, R. (2018, October 23). Union ready to seek wage rises after VAT increase.

The Tribune. http://www.tribune242.com/news/2018/o ct/23/union-ready-seek-wage-rises-aftervat-increase/

World Bank. (2019). Country profile:

Bahamas.

https://data.worldbank.org/country/baha mas-the?view=chart 